\title{
Measurement of Potential Tourism Destination: A Case Study
}

\author{
POPY RUFAIDAH \\ Universitas Padjadjaran, Faculty of Economics and Business, Bandung 40132, Indonesia \\ Email correspondence: popy.rufaidah@fe.unpad.ac.id
}

\begin{abstract}
This study was aimed to discuss study result to measure destination potentials in West Java, Indonesia that was conducted empirically. Based on the literature, there is still no clarity in technic and how to measure tourism destination potentials. Therefore, this paper has an advantage as a paper that discusses the measurement of tourism destination potentials with quantitative approach. The research method employed for the research reported in this paper was the case study research method. The research completion reported in this paper took place over a nine month period (from April to December), and involved field surveys to measure and analyse potential destination tourism object and their development. Potential tourism destination is the attractiveness contained in an area to be developed as untapped or not managed well to become a qualified attraction and able to attract tourists to come to the area. The formula proposed by Beciu and Hontus (2014) was adopted in this study to measure the potential of tourism destinations, namely, (1) Index of Global Tourist Demand Change, (2) Index of Domestic and Foreign Demand Variation in Time; (3) Indicator of Total Accomodation Capacity Evolution; and (4) Index of Global Tourist Demand Distribution. The study conclude that the priority for West Java Province to develop the tourism destination are, firstly, Subang Regency, secondly, Sukabumi Regency and lastly, Depok City. The recommendation of the study is proposed that in measuring the potential tourism destination, it is very important for every government to consider the ranking of each regencies / cities based on above mentoned index. In particular, the government requires a ranking for each area (regencies and or cities) in allocating the budget.
\end{abstract}

Key words: Measurement, Potential tourism destination, West Java, Indonesia.

\section{Mengukur Potensi Destinasi Parawisata: Sebuah Studi Kasus}

\begin{abstract}
Abstrak
Penelitian ini bertujuan untuk membahas hasil studi untuk mengukur potensi tujuan di Jawa Barat, Indonesia yang dilakukan secara empiris. Berdasarkan literatur, masih belum ada kejelasan dalam teknik dan bagaimana mengukur pariwisata potensi tujuan. Oleh karena itu, makalah ini memiliki keuntungan sebagai kertas yang membahas pengukuran potensi destinasi pariwisata dengan pendekatan kuantitatif. Metode penelitian yang digunakan untuk penelitian dilaporkan dalam makalah ini adalah metode penelitian studi kasus. Selesainya penelitian dilaporkan dalam paper ini berlangsung selama sembilan bulan (dari bulan April sampai Desember), dan survei lapangan yang terlibat untuk mengukur dan menganalisa potensi obyek wisata tujuan dan perkembangan mereka. tujuan wisata potensial adalah daya tarik yang terdapat di daerah untuk dikembangkan sebagai yang belum dimanfaatkan atau tidak dikelola dengan baik untuk menjadi daya tarik berkualitas dan mampu menarik wisatawan untuk datang ke daerah. Rumus yang diusulkan oleh Beciu dan Hontus (2014) diadopsi dalam penelitian ini untuk mengukur potensi destinasi pariwisata, yaitu, (1) Indeks Global Tourist Permintaan Perubahan, (2) Indeks Domestik dan Asing Variasi Permintaan di waktu; (3) Indikator Jumlah Accomodation Kapasitas Evolution; dan (4) Indeks Global Tourist Menuntut Distribusi. Studi ini menyimpulkan bahwa prioritas untuk Provinsi Jawa Barat untuk mengembangkan tujuan wisata adalah, pertama, Kabupaten Subang, kedua, Kabupaten Sukabumi dan terakhir, Kota Depok. Rekomendasi dari penelitian ini diusulkan bahwa dalam mengukur tujuan wisata potensial, sangat penting bagi setiap pemerintah untuk mempertimbangkan peringkat masing-masing kabupaten / kota berdasarkan atas indeks mentoned. Secara khusus, pemerintah memerlukan peringkat untuk masing-masing daerah (kabupaten dan atau kota) dalam mengalokasikan anggaran.
\end{abstract}

Kata kunci: Mengukur, Potensi destinasi parawisata, Jawa Barat, Indonesia. 


\section{ABSTRACT}

This study was aimed to discuss study result to measure destination potentials in West Java, Indonesia that was conducted empirically. Based on the literature, there is still no clarity in technique and how to measure tourism destination potentials. Therefore, this paper has an advantage as a paper that discusses the measurement of tourism destination potentials with quantitative approach. The research method employed for the research reported in this paper was the case study research method. The research completion reported in this paper took place over a nine month period (from April to December), and involved field surveys to measureand analyse potential destination tourism object and their development. Potential tourism destination is the attractiveness contained in an area to be developed as untapped or not managed well to become a qualified attraction and able to attract tourists to come to the area. In analyzing and measuring the potential of tourism, one of the approaches by Beciu and Hontus (2014) could be used as one method of measuring the potential of tourism, where they use indicators of tourist traffic as the basis for measuring the potential of a tourism destination. The formula proposed by Beciu and Hontus (2014) was adopted in this study to measure the potential of tourism destinations, namely, (1) Index of Global Tourist Demand Change, (2) Index of Domestic and Foreign Demand Variation in Time; (3) Indicator of Total Accomodation Capacity Evolution; and (4) Index of Global Tourist Demand Distribution. This study used the same method used by Hontus, conducting analysis in all regencies/cities in West Java for tourism conditions during 2009-2013 with a total of 26 regencies/cities (Pangandaran Regency was not analyzed because only founded in 2012). Data used were taken from National Central Bureau of Statistics (CBS), CBS of West Java Province, and several CBS Regency/City. This study used the same method used by Hontus, conducting analysis in all regencies/cities in West Java for tourism conditions during 20092013 with a total of 26 regencies/cities (Pangandaran Regency was not analyzed because only founded in 2012). Data used were taken from National Central Bureau of Statistics (CBS), CBS of West Java Province, and several CBS Regency/ City. The analysis result showed that Subang Regency is rank as the highest position in comparison with other regencies/cities in West Java, with average growth in the number of overnight stay from 2010-2013 amounted to 69.46\%. For Sukabumi City, the analysis shows that this area has the advantage of foreign tourist visit,among all can be seen that, this area is the highest with an average growth in the number of foreign tourists from the year 2010-2013 amounted to $152.08 \%$. Depok City has the third highest value compared to other regencies/cities in West Java, with average growth in the number of accommodation of the year 2010-2013 amounted to $27.08 \%$. The study conclude that the priority for West Java Province to develop the tourism destination are, firstly, Subang Regency, secondly, Sukabumi Regency and lastly, Depok City. The recommendation of the study is proposed that in measuring the potential tourism destination, it is very important for every government to consider the ranking of each regencies / cities based on above mentoned index. In particular, the government requires a ranking for each area (regencies and or cities) in allocating the budget.

\section{INTRODUCTION}

This research was resulted from a study conducted by writer as an advisor for provincial government of West Java in 2014 to develop tourism of West Java, one of the provinces in Indonesia. The task of an adviser was: (1) Mapping of destination potential priority of tourism in West Java, (2) Preparing scientific studies of potentials and opportunities of tourism destination development, (3) Planning priority development of West Java's destination tourism scientifically, and (4) Preparing priority of development planning of West Java's tourism destination. Based on the tasks of advisor, one of the studies conducted was measuring the potential tourism destination in West Java that is re-written in this article. The study result of the measurement of potential tourism destination in West Java had been featured in Advisor Monthly Report as the result of advisor study. During the preparation of this study result, many inputs were given from variety parties, such as the Head of Tourism and Cultural Department, Head of Tourism of West Java, Head of Tourism on the levels of city and regency in all over West Java, as well as four advisor colleagues.

This study was aimed to discuss study result to measure destination potentials in West Java that was 


\section{JURNAL BISNIS \& MANAJEMEN}

ISSN 1412 - 3681

conducted empirically. Based on the literature, there is still no clarity in technic and how to measure tourism destination potentials. Therefore, this paper has an advantage as a paper that discusses the measurement of tourism destination potentials with quantitative approach. One of the studies had been conducted was by Hontus (2014), namely tourist traffic analysis by using indicators of tourism demand and supply) through 14 measurement formulas. However, this study adopts the first four formulas that are relevant to the condition of West Java. Therefore, this study can be used as one of scientific studies to justify the decision making of West Java government in setting which tourism destination to be developed as one of high-class destinations.

\section{West Java Profile}

This study was conducted in West Java Province, one of 32 provinces in Indonesia. West Java Province has the largest population, 46,0299.66 thousands inhabitants. Based on Central Bureau of Statistic of Indonesia, this province has a high population growth rate. The population of West Java inhabitants increased $1.5 \%$ from the previous year, 45,340.79 thousands inhabitants in 2013. The average rate of population growth of West Java was $1.64 \%$ annually (Pusdalisbang; January 2014).

The land area of Province of West Java covers $35,377.76 \mathrm{~km} 2$ with coastline of $724.85 \mathrm{~km}$. Administratively, West Java Province is divided into 27 cities and countries, namely 18 countries and 9 cities. The population of West Java is spread in 26 cities/countries, 625 counties, and 5,899 villages. The largest population is in Bogor Regency as much as 4,966,621 inhabitants (11.03\%), while the smallest population is in Banjar City with 192,903 inhabitants $(0,43 \%)$.

A quarter of West Java population lives in buffer zone of Capital (Bogor Regency, Bogor City, BekasiRegency, Bekasi City, and Depok City, as much as 11,930,991 or 26 percent of total population of West Java). Furthermore, a fifth of West Java population lives in Bandung area/Province Capital (Bandung Regency, West Bandung Regency, Bandung City, and CimahiCity) as much as $8,670,501$ inhabitants or $18 \%$ of total population of West Java. If the population who lives in buffer zone and Bandung Area are added, total
Jurnal Bisnis \& Manajemen, 2016, Vol. XVII, No. 2, 85-94

population of both areas is $44 \%$ of total population of West Java. It can be seen that half of population of West Java lives in both areas.

In terms of performance of tourist arrivals, West Java is not as good as other provinces (for example: Province of Bali), which in 2014 reached 1,962,639 people; while the domestic tourists visit/domestic amounted 33,617,999. Compared with EU area with total area of $4,422,773 \mathrm{~km} 2$ with a total population of $456,285,839$ inhabitants, West Java Province is one of provinces that offers a number of tourism potential, namely natural tourist attractions (mountains, jungles, oceans), artificial tourisms, arts and culture. One of the wonders that exists in West Java is volcanic crater of Tangkuban Parahu Mountain in Subang Regency, which is the only volcanic crater that can be seen from a distance the human eye.

In addition to its variety of uniqueness, West Java has a number of problems in tourism, as stated in the Local Government Work Plan for the West Java province (2016) , namely the lack of supporting facilities of tourism and tourism infrastructure, the low quality accessibility to tourism objects and the less interesting packaging of tourist areas in West Java; destination promotional efforts that are yet to be integrated among the level of the Central Government, Provincial Government, Local Government; as well as the lack of cooperation between the Tourism Associations and the Tourism Industry Associations; the uneven spread of printed promotional materials, the incomprehensive promotional materials in the media campaign displayed through electronic media, the lack of participation of local governments in following the tourism promotional events in and outside the country, the lack of cross marketing cooperation of government and private organizations as well and discontinuity of cultural and tourism diplomacy activities.

Potential tourism destination is defined as ageographic area that has the capacity to evolve in the future that are within one or more administrative regions in which there are tourist attractions, public facilities, tourism facilities, accessibility, and community that are interrelated and complete the realization of tourism. Through the study of the measurement of potential tourism destination, this paper discusses 
the profile management of local tourism attraction that is everything that has uniqueness, beauty, and value in the form of diversity in natural resources, culture, and man-made creation or destination of tourists visit.

\section{RESEARCH METHODS}

The research method employed for the research reported in this paper was the case study research method. A case study is an empirical inquiry that investigates a contemporary phenomenon within its real life context, when the boundaries between phenomenon and context are not clearly evident, and in which multiple sources of evidence are used (Yin 2003). The research completion reported in this paper took place over a nine month period (from April to December), and involved field surveys to measure and analyse potential destination tourism object and their development. The research completion also involved intense biweekly discussion among four other advisors with various expertise background (i.e. tourism, environment, planner, social). The author also involved staff at the Tourism and Culture Office of West Java as well as three other research assistants in evaluating 517 destination tourism objects in West Java region. So that, Siggelkow (2007:22) stated that the ability to get closer to theoretical constructs is particularly important in the context of longitudinal research that tries to unravel the underlying dynamics of phenomena that play out over time. As scholars have increasingly begun to appreciate the role of dynamic processes (e.g., path dependency or evolutionary processes), rich longitudinal research is needed to provide the details of how these processes actually play out."

In order to evaluate the results of the study, a formal meeting was performed in order to confirm the result of the study with the real situation at the regencies and cities that were studied. As the case study method was used, its benefits to fulfill the aim of the paper, that is to broaden the understanding on the potentiality of hundred of tourism destination objects in West Java region. Data also was gathered through semi-structured interviews, review of documents and observations. The interviews were conducted with the head of tourism at the Tourism and Culture offices in regencies and cities in the Wes Java region; in order to understand their perceptions and experiences with regards to destination tourism objects. Data collected during the interviews were sorted, coded and categorized into themes. There was also a review of relevant literatures relating to the subject that assisted in developing further prompting questions during the interviews.

Based on the final report of the of West Java Tourism Development Advisor (2014:III-2), West Java province has many tourist attractions that are spread across the regencies and cities. Natural attractions can be said to be the main attraction in West Java in the form of mountains, beaches, waterfalls, lakes, karsts cliffs, etc. The tourist attractions are as much as 561 objects, with details of 289 natural tourist attractions, 104 cultural attractions, and 168 special interest tourist attractions. Special interest tours are mostly located in Bogor City and Bogor Regency (66 tourist attractions). Natural attractions are most numerous in Bandung City, Bandung Regency, West Bandung Regency (64 tourist attractions). These region is indeed attractive where its natural conditions i.e. mountains provide a lot of beautiful scenery. In addition to natural attractions, in Bandung City, Bandung Regency, and West Bandung Regency, these regions become a tourist destination with a wealth of cultural tourist attraction (25 tourist attractions).

\section{Measurement Of The Potential Destination Tourisms}

Potential tourism destination is the attractiveness contained in an area to be developed as untapped or not managed well to become a qualified attraction and able to attract tourists to come to the area. In analyzing and measuring the potential of tourism, one of the approaches by Beciu and Hontus (2014) could be used as one method of measuring the potential of tourism, where they use indicators of tourist traffic as the basis for measuring the potential of a tourism destination. The formula proposed by Beciu and Hontus (2014) was adopted in this study to measure the potential of tourism destinations, namely, (1) Index of Global Tourist Demand Change, which is a measure to see growth in the number of tourists staying overnight by comparing the number of overnight tourists this year the number of tourists staying overnight the previous year; (2) Index of Domestic and Foreign Demand Variation in Time, which is a measure to see growth in the number of tourists both domestic and foreign 
tourists by comparing the number of tourists this year with the previous year of the number of tourists; (3) Indicator of Total Accomodation Capacity Evolution, which is a measure to see growth in the number of accommodation by comparing the number of inn this year with the number of inn the previous year; and (4) Index of Global Tourist Demand Distribution, which is a measure to indicate the ratio between the number of domestic tourists or foreign tourists to the total of all tourists by comparing the number of domestic tourists or foreign tourists this year with the total number of tourists the previous year.

Hontus (2013) also conducted a study on how to promote existing tourism objects by analyzing tourist visits in tourism supply and demand using the most representative tourism indicators. The object is "Valahia" Hotel, in the City of Moreni, Romania to determine whether the area is sought after by the tourists. From the result from the analysis of indicators, it can be seen that the ValahiaHotel was more attractive to tourists both foreign and Romanian tourists as it had many parks, scenery, and some special exhibitions. Also, because the hotel is situated in a strategic area that became the center of economic and tourism activities.

Once again, Hontus (2014) conducted a study on the supply and demand of tourism in one of the tourist accommodation in the Logs resort by calculating and interpreting the most representative tourism indicators at the object of "Maia House" located in the resort Logs, Prahova County that had new construction accompanied by high standards of comfort and security. The result showed that the economic and social development should be combined with the development of tourism as it will contribute to the overall development of the region, the mix of this development in turn will lead to an increase in tourist traffic.

This study used the same method used by Hontus, conducting analysis in all regencies/cities in West Java for tourism conditions during 2009-2013 with a total of 26 regencies/cities (Pangandaran Regency was not analyzed because only founded in 2012). Data used were taken from National Central Bureau of Statistics (CBS), CBS of West Java Province, and several CBS Regency/ City. Here is the result of data processing in all regencies/cities.

Table 1. Results of Data Processing - Average Score and Ranking for all regencies/cities

\begin{tabular}{|c|c|c|c|c|c|c|c|c|c|c|c|c|c|}
\hline \multirow{4}{*}{$\begin{array}{c}\text { Regencies / cities } \\
\text { (Average Score \& Ranking) }\end{array}$} & & \multicolumn{12}{|c|}{ Indicators } \\
\hline & & \multicolumn{2}{|c|}{1} & \multicolumn{4}{|c|}{2} & \multicolumn{2}{|c|}{3} & \multicolumn{4}{|c|}{4} \\
\hline & & \multicolumn{2}{|c|}{$\begin{array}{l}\text { Index of Global Tourist } \\
\text { Demand Change }\end{array}$} & \multicolumn{4}{|c|}{$\begin{array}{l}\text { Index of Indonesian and } \\
\text { Foreign Demand Variation } \\
\text { in Time }\end{array}$} & \multirow{2}{*}{\multicolumn{2}{|c|}{$\begin{array}{l}\text { Indicator of Total } \\
\text { Accommodation } \\
\text { Capacity Evolution }\end{array}$}} & \multicolumn{4}{|c|}{$\begin{array}{l}\text { Index of Global Tourist } \\
\text { Demand Distribution }\end{array}$} \\
\hline & & & & Indone & (a) & Foreign & & & & Indon & (a) & Fore & (b) \\
\hline \multirow[t]{2}{*}{ Bogor Regencies } & & 109.03 & & 106.91 & & 129.05 & & 94.19 & & 98.12 & & 1.88 & \\
\hline & ranking & & 20 & & 20 & & 12 & & 26 & & 18 & & 9 \\
\hline \multirow[t]{2}{*}{ Sukabumi Regencies } & & 107.17 & & 110.17 & & 88.29 & & 98.21 & & 99.26 & & 0.74 & \\
\hline & ranking & & 21 & & 16 & & 20 & & 23 & & 15 & & 13 \\
\hline \multirow[t]{2}{*}{ Cianjur Regencies } & & 110.99 & & 109.39 & & 129.33 & & 96.38 & & 99.34 & & 0.67 & \\
\hline & ranking & & 18 & & 18 & & 11 & & 25 & & 14 & & 14 \\
\hline \multirow[t]{2}{*}{ Bandung Regencies } & & 121.58 & & 106.89 & & 197.18 & & 122.09 & & 96.44 & & 3.56 & \\
\hline & ranking & & 11 & & 21 & & 4 & & 2 & & 23 & & 4 \\
\hline \multirow[t]{2}{*}{ Garut Regencies } & & 135.51 & & 144.39 & & 102.21 & & 103.95 & & 99.75 & & 0.25 & \\
\hline & ranking & & 3 & & 4 & & 18 & & 7 & & 10 & & 17 \\
\hline \multirow[t]{2}{*}{ Tasikmalaya Regencies } & & 140.17 & & 133.69 & & 182.05 & & 104.55 & & 99.55 & & 0.46 & \\
\hline & ranking & & 2 & & 5 & & 5 & & 5 & & 13 & & 15 \\
\hline \multirow[t]{2}{*}{ Ciamis Regencies } & & 105.87 & & 102.50 & & 82.77 & & 101.21 & & 97.77 & & 2.23 & \\
\hline & ranking & & 22 & & 23 & & 22 & & 15 & & 19 & & 8 \\
\hline \multirow[t]{2}{*}{ Kuningan Regencies } & & 119.91 & & 111.15 & & 84.20 & & 101.41 & & 99.65 & & 0.35 & \\
\hline & ranking & & 13 & & 13 & & 21 & & 14 & & 12 & & 16 \\
\hline
\end{tabular}


Continue of Table 1. Results of Data Processing - Average Score and Ranking for all regencies/cities

\begin{tabular}{|c|c|c|c|c|c|c|c|c|c|c|c|c|c|}
\hline \multirow{4}{*}{$\begin{array}{c}\text { Regencies / cities } \\
\text { (Average Score \& Ranking) }\end{array}$} & & \multicolumn{12}{|c|}{ Indicators } \\
\hline & & \multicolumn{2}{|c|}{1} & \multicolumn{4}{|c|}{2} & \multicolumn{2}{|c|}{3} & \multicolumn{4}{|c|}{4} \\
\hline & & \multicolumn{2}{|c|}{$\begin{array}{l}\text { Index of Global Tourist } \\
\text { Demand Change }\end{array}$} & \multicolumn{4}{|c|}{$\begin{array}{l}\text { Index of Indonesian and } \\
\text { Foreign Demand Variation } \\
\text { in Time }\end{array}$} & \multicolumn{2}{|c|}{$\begin{array}{l}\text { Indicator of Total } \\
\text { Accommodation } \\
\text { Capacity Evolution }\end{array}$} & \multicolumn{4}{|c|}{$\begin{array}{l}\text { Index of Global Tourist } \\
\text { Demand Distribution }\end{array}$} \\
\hline & & & & Indone & (a) & Foreign & & & & Indonesia & (a) & Foreig & \\
\hline \multirow[t]{2}{*}{ Cirebon Regencies } & & 103.52 & & 104.60 & & 139.96 & & 102.69 & & 99.94 & & 0.07 & \\
\hline & ranking & & 25 & & 22 & & 9 & & 11 & & 3 & & 24 \\
\hline \multirow[t]{2}{*}{ Majalengka Regencies } & & 114.50 & & 108.20 & & 50.56 & & 100.00 & & 99.99 & & 0.01 & \\
\hline & ranking & & 25 & & 22 & & 9 & & 11 & & 3 & & 24 \\
\hline \multirow[t]{2}{*}{ Sumedang Regencies } & & 133.13 & & 150.17 & & 216.07 & & 100.28 & & 99.83 & & 0.17 & \\
\hline & ranking & & 4 & & 3 & & 2 & & 16 & & 8 & & 19 \\
\hline \multirow[t]{2}{*}{ Indramayu Regencies } & & 124.52 & & 117.74 & & 60.56 & & 98.27 & & 99.83 & & 0.18 & \\
\hline & ranking & & 10 & & 8 & & 24 & & 22 & & 9 & & 18 \\
\hline \multirow[t]{2}{*}{ Subang Regencies } & & 171.64 & & 166.20 & & 107.40 & & 101.65 & & 98.22 & & 1.78 & \\
\hline & ranking & & 1 & & 1 & & 17 & & 13 & & 17 & & 10 \\
\hline \multirow[t]{2}{*}{ Purwakarta Regencies } & & 105.32 & & 109.84 & & 118.40 & & 110.85 & & 95.85 & & 4.15 & \\
\hline & Ranking & & 24 & & 17 & & 15 & & 3 & & 24 & & 3 \\
\hline \multirow[t]{2}{*}{ Karawang Regencies } & & 101.73 & & 101.27 & & 81.83 & & 102.78 & & 99.85 & & 0.15 & \\
\hline & ranking & & 26 & & 25 & & 23 & & 9 & & 5 & & 22 \\
\hline \multirow[t]{2}{*}{ Bekasi Regencies } & & 121.11 & & 112.47 & & 133.80 & & 103.57 & & 88.96 & & 11.05 & \\
\hline & ranking & & 12 & & 12 & & 10 & & 8 & & 26 & & 1 \\
\hline \multirow[t]{2}{*}{ West Bandung Regencies } & & 128.13 & & 129.79 & & 214.00 & & 108.78 & & 99.20 & & 0.80 & \\
\hline & ranking & & 5 & & 6 & & 3 & & 4 & & 16 & & 11 \\
\hline \multirow[t]{2}{*}{ Bogor City } & & 126.97 & & 127.21 & & 142.82 & & 99.36 & & 97.30 & & 2.70 & \\
\hline & ranking & & 7 & & 7 & & 7 & & 20 & & 22 & & 5 \\
\hline \multirow[t]{2}{*}{ Sukabumi City } & & 113.04 & & 110.92 & & 252.08 & & 99.37 & & 99.83 & & 0.17 & \\
\hline & ranking & & 16 & & 14 & & 1 & & 19 & & 7 & & 20 \\
\hline \multirow[t]{2}{*}{ Bandung City } & & 112.43 & & 115.57 & & 108.27 & & 104.32 & & 95.73 & & 4.27 & \\
\hline & ranking & & 17 & & 10 & & 16 & & 6 & & 25 & & 2 \\
\hline Cirebon City & & 109.67 & & 102.40 & & 140.96 & & 97.54 & & 97.43 & & 2.57 & \\
\hline & ranking & & 19 & & 24 & & 8 & & 24 & & 21 & & 6 \\
\hline Bekasi City & & 113.96 & & 115.96 & & 127.67 & & 101.67 & & 97.45 & & 2.55 & \\
\hline & ranking & & 15 & & 9 & & 13 & & 12 & & 20 & & 7 \\
\hline Depok City & & 124.60 & & 157.98 & & 151.17 & & 127.08 & & 99.84 & & 0.16 & \\
\hline & ranking & & 8 & & 2 & & 6 & & 1 & & 6 & & 21 \\
\hline Cimahi City & & 127.50 & & 114.75 & & $0.00 *$ & & $100.00 * *$ & & $100.00 * *$ & & $0.00 *$ & \\
\hline & ranking & & 6 & & 11 & & 26 & & 17 & & 1 & & 26 \\
\hline Tasikmalaya City & & 124.55 & & 110.18 & & 100.92 & & 98.39 & & 99.69 & & 0.79 & \\
\hline & ranking & & 9 & & 15 & & 19 & & 21 & & 11 & & 12 \\
\hline Banjar City & & 105.66 & & 94.96 & & 121.18 & & 102.78 & & 99.89 & & 0.11 & \\
\hline & ranking & & 23 & & 26 & & 14 & & 9 & & 4 & & 23 \\
\hline
\end{tabular}

From the above result, ranking for each indicator in all regencies/cities was done by calculating the average of each indicator, where the regency or city that has the highest average value will receive the highest rank; regency or city with the greatest number of highest rank (grading results attached) is projected to have a great tourism potential. After processing, the three regions that obtained the highest rank are Subang Regency, Sukabumi City and Depok City. 
Table 1. Results of Data Processing - Subang Regency

\begin{tabular}{|c|c|c|c|c|c|c|}
\hline \multirow{4}{*}{ Year } & \multicolumn{6}{|c|}{ Indicators } \\
\hline & 1 & 2 & & 3 & 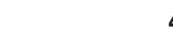 & \\
\hline & \multirow[t]{2}{*}{$\begin{array}{c}\text { Index of Global Tourist } \\
\text { Demand Change }\end{array}$} & \multicolumn{2}{|c|}{$\begin{array}{c}\text { Index of Indonesian and } \\
\text { Foreign Demand Variation } \\
\text { in Time }\end{array}$} & \multirow{2}{*}{$\begin{array}{l}\text { Indicator of Total } \\
\text { Accommodation } \\
\text { Capacity Evolution }\end{array}$} & \multicolumn{2}{|c|}{$\begin{array}{l}\text { Index of Global Tourist } \\
\text { Demand Distribution }\end{array}$} \\
\hline & & Indonesia (a) & Foreign (b) & & Indonesia (a) & Foreign (b) \\
\hline 2010 & 326.67 & 329.58 & 71.53 & 101.28 & 98.21 & 1.79 \\
\hline 2011 & 158.48 & 135.68 & 143.08 & 106.33 & 98.12 & 1.88 \\
\hline 2012 & 131.77 & 118.57 & 81.86 & 103.57 & 98.69 & 1.31 \\
\hline 2013 & 69.62 & 80.96 & 133.14 & 95.40 & 97.87 & 2.13 \\
\hline
\end{tabular}

The analysis result showed that Subang Regency has index value of 1 the highest in comparison with other regencies/cities in West Java, with average growth in the number of overnight stay from 2010-2013 amounted to $69.46 \%$. This was due to growth in the number of tourists who come to Subang Regency is also experiencing significant growth every year, one of which can be seen in the index $2 a$ where Subang Regency has the highest average growth number of domestic tourists from the year 2010 to 2013 amounted to $66.20 \%$. compared to other provinces.

Based on the measurement of tourism destination potentials, Subang Regency is well-known for its globally-acknowledged advantage namely Tangkuban Parahu Volcano and Hot Springs in Ciater. Both of these destinations are one of the mainstays of tourism in West Java. Based on the results of measurements of the potential of the tourism destination, these destinations are projected as world-class destinations.

Table 2. Results of Data Processing - Sukabumi City

\begin{tabular}{|c|c|c|c|c|c|c|}
\hline \multirow{4}{*}{ Year } & \multicolumn{6}{|c|}{ Indicators } \\
\hline & 1 & 2 & & 3 & 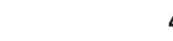 & \\
\hline & \multirow[t]{2}{*}{$\begin{array}{l}\text { Index of Global Tourist } \\
\text { Demand Change }\end{array}$} & \multicolumn{2}{|c|}{$\begin{array}{l}\text { Index of Indonesian and } \\
\text { Foreign Demand Variation } \\
\text { in Time }\end{array}$} & \multirow{2}{*}{$\begin{array}{l}\text { Indicator of Total } \\
\text { Accommodation } \\
\text { Capacity Evolution }\end{array}$} & \multicolumn{2}{|c|}{$\begin{array}{l}\text { Index of Global Tourist } \\
\text { Demand Distribution }\end{array}$} \\
\hline & & Indonesia (a) & Foreign (b) & & Indonesia (a) & Foreign (b) \\
\hline 2010 & 91.97 & 100.28 & 21.00 & 103.13 & 99.94 & 0.06 \\
\hline 2011 & 98.05 & 90.26 & 98.41 & 93.94 & 99.94 & 0.06 \\
\hline 2012 & 137.16 & 137.69 & 167.74 & 106.45 & 99.92 & 0.08 \\
\hline 2013 & 124.98 & 115.45 & 721.15 & 93.94 & 99.52 & 0.48 \\
\hline
\end{tabular}

Although the average growth of overnight stay of tourists in Subang was not too high compared to other regencies/cities, but the high growing number of tourists indicates that this area has a special attraction to encourage public interest in visiting Subang Regency. With such a high number of visits, the tourism sector can be encouraged to continue to develop and innovate in tourist attractions in this area. Tourism development, whether in terms of attractiveness, infrastructure, natural and social environment in this area is critical, given that Subang Regency ownsa high number of visits as capital
For Sukabumi City, the analysis shows that this area has the advantage of foreign tourist visit,among all can be seen from index $2 b$ in this area which is the highest with an average growth in the number of foreign tourists from the year 2010-2013 amounted to $152.08 \%$. Various attractions in this area, which is dominated by beaches and natural attractions and is in the same region with SukabumiRegncy, has attracted the interest of tourists to visit and tour here. This is reinforced by the the highest value of index $4 \mathrm{~b}$ of Sukabumi City, that indicates that the ratio pf the total number of tourists in this area the getting 
higher from year to year with an average growth ratio of $184.32 \%$.

From the above data, it is shown that Sukabumi City has the advantage of high tourist visits. To maintain and improve the tourist visit to boost the tourism sector in this region, it is necessary to develop programs of local stakeholders. Given the tourist resorts in Sukabumi City are in one region with tourist resorts in Sukabumi Region, it is also necessary to synergize both of these two areas to produce beaches-andnature-based tourist area.
Mountain, Ciptagelar Village, Ujung Genteng and Pangumbahan Beach, Clmaja Beach, and Cikaso Waterfall.

Depok City has the highest index value 3 compared to other regencies/cities in West Java, with average growth in the number of accommodation of the year 2010-2013 amounted to $27.08 \%$. This shows that this area has had relatively adequate supporting facilities also considering this area is located in the same area with Jakarta, the capital of Indonesia, that is heavily laden with various activities. In addition, the number

Table 2. Results of Data Processing - Sukabumi City

\begin{tabular}{|c|c|c|c|c|c|c|}
\hline \multirow{4}{*}{ Year } & \multicolumn{6}{|c|}{ Indicators } \\
\hline & 1 & 2 & & 3 & & \\
\hline & \multirow[t]{2}{*}{$\begin{array}{l}\text { Index of Global Tourist } \\
\text { Demand Change }\end{array}$} & \multicolumn{2}{|c|}{$\begin{array}{l}\text { Index of Indonesian and } \\
\text { Foreign Demand Variation } \\
\text { in Time }\end{array}$} & \multirow{2}{*}{$\begin{array}{l}\text { Indicator of Total } \\
\text { Accommodation } \\
\text { Capacity Evolution }\end{array}$} & \multicolumn{2}{|c|}{$\begin{array}{l}\text { Index of Global Tourist } \\
\text { Demand Distribution }\end{array}$} \\
\hline & & Indonesia (a) & Foreign (b) & & Indonesia (a) & Foreign (b) \\
\hline 2010 & 91.97 & 100.28 & 21.00 & 103.13 & 99.94 & 0.06 \\
\hline 2011 & 98.05 & 90.26 & 98.41 & 93.94 & 99.94 & 0.06 \\
\hline 2012 & 137.16 & 137.69 & 167.74 & 106.45 & 99.92 & 0.08 \\
\hline 2013 & 124.98 & 115.45 & 721.15 & 93.94 & 99.52 & 0.48 \\
\hline
\end{tabular}

By measuring the potential of tourism destinations, Sukabumi Regency, one of the districts that has been known for the excellence of the beauty of the sea namely PelabuhanRatu. Pelabuhan Ratu becomes one of the top sites for surfers to try the waves that are known to be very fierce. This destination becomes one of the mainstays of tourism in West Java. Based on the measurement result of the tourism destination potential, the destination is projected as a world-class destination. Other tourism destinations potential to be developed are National Park of HalimunSalak of visits in Depok City was also relatively high, especially visits of domestic tourists with an average growth of $2010-2013$ amounted to $57.97 \%$ slightly below Subang Regency.

It is noticeable that Depok City has an advantage in the number of accommodation and the number of domestic tourist visits. However, based on the potential tourism destinations in Depok City, many who know that tourism in this area is not too much, there is only artificial tourism is often a destination

Table 3. Results of Data Processing - Depok City

\begin{tabular}{|c|c|c|c|c|c|c|}
\hline \multirow{4}{*}{ Year } & \multicolumn{6}{|c|}{ Indicators } \\
\hline & 1 & 2 & & 3 & & \\
\hline & \multirow[t]{2}{*}{$\begin{array}{l}\text { Index of Global Tourist } \\
\text { Demand Change }\end{array}$} & \multicolumn{2}{|c|}{$\begin{array}{c}\text { Index of Indonesian and } \\
\text { Foreign Demand Variation } \\
\text { in Time }\end{array}$} & \multirow{2}{*}{$\begin{array}{l}\text { Indicator of Total } \\
\text { Accommodation } \\
\text { Capacity Evolution }\end{array}$} & \multicolumn{2}{|c|}{$\begin{array}{l}\text { Index of Global Tourist } \\
\text { Demand Distribution }\end{array}$} \\
\hline & & Indonesia (a) & Foreign (b) & & Indonesia (a) & Foreign (b) \\
\hline 2010 & 101.03 & 127.86 & 288.52 & 100.00 & 99.79 & 0.21 \\
\hline 2011 & 148.49 & 117.93 & 64.20 & 100.00 & 99.89 & 0.11 \\
\hline 2012 & 100.76 & 58.59 & 115.04 & 133.33 & 99.78 & 0.22 \\
\hline 2013 & 148.10 & 327.52 & 136.92 & 175.00 & 99.91 & 0.09 \\
\hline
\end{tabular}

Source: • final report of the of West Java Tourism Development Advisor (2014:IV-49)

- Results Data Processing CBS "Statistics Hotels and Accommodations in West Java 2009-2013" 


\section{JURNAL BISNIS \& MANAJEMEN}

ISSN 1412 - 3681

for family tourism destination. One of the icons of Depok City is becoming the other, where it operates one of the top universities in Indonesia. Thus, the recommendations suggested in the development of tourism in the city of Depok is an increase in the maintenance and marketing of existing objects in order to continue to attract and boost the number of tourist visits.

\section{CONCLUSION}

From the description and analysis above, the study can map the priority of potential tourism destinations in West Java as follows: (1) Tourism Destinations of Subang Regency. With the growing number of staying overnight and a high number of tourists compared to other regencies/cities in West Java, this area is projected to have a tourism potential that can be developed. Tourist attraction in this area consists of natural and historical attractions that require special attention from both local and provincial governments to be developed, in terms of attractiveness, infrastructure, natural and social environment, to the process of planning and marketing. Thus, advantages owned by Subang Regency can be optimized to become main tourist destinations in West Java.

(2) Tourism Destinations of Sukabumi City. With the growing number of foreign travelers and foreign tourist comparison to the total tourists higher than other regencies/cities in West Java, this area is projected to have a tourism potential that can be developed. Tourist attractions in the area is dominated by natural attractions, especially coastal tourism which requires special attention from both local and provincial government to be developed in terms of attractiveness, infrastructure, natural and social environment, to the process of planning and marketing. Moreover, considering tourist attractions in SukabumiCity are in the same region with tourist attractions of SukabumiRegency, it is also necessary to synergize between these two areas to produce coastal-based and nature-based tourism. Thus, advantages owned by SukabumiCity can be optimized to become the main tourist destinations in West Java.

(3) Tourism Destinations in Depok City. With the growth in the number of accommodation and the high number of domestic tourists compared to other regencies/cities in West Java, this area is projected to have tourism potential that can be developed. Tourist attractions in the area are dominated by artificial tourism such as water recreation and golf arena suitable for family visit, where these objects may continue to grow if supported by both local and provincial government, either in the form of infrastructure and marketing supports. Thus, the advantages of Depok City can be optimized to become main tourism destinations in West Java.

\section{RECOMMENDATION}

Measurement of potential tourism destination is very important for every government. In particular, the government requires a ranking for each area (regencies and or cities) in allocating the budget. The more obvious the results of the assessment for each regions/cities based on tourism potential, the easier for the government to allocate funds for regional development. The more precise figures on the data of each regency and or city the more precise the ranking process in determining of potential tourism destinations in a region i.e. West Java Region. Hontus's formula to measure the potential of the destination can be done on a regular basis such as measuring annual tourism destination potential for every village, district, town and region.

If the government can announce the results of the grading for the whole regencies/cities/town in a country on a regular basis, then a ranking has become an attraction for potential investors. The results of measuring the tourism potential destinations will be very beneficial for the local government itself and provide benefits to the tourism stakeholder in an area. Further study, may empirically tested the other ten Hontus's formula to measure the performance of tourist traffics as othter alternatif to measure of tourism potential.

\section{REFERENCES}

Beciu, S. \& Hontus, A.C., (2014). Tourism Potential for Regional Development in the NorthEast Region of Romania. Journal of Eastern Europe Research in Business \& Economics, 1-10. 
Hontus, A.C., (2014). Analysis Of Tourism Demand And Supply - One Of The Essential Elements Of An Area In Tourism Planning, Scientific Papers Series Management, Economic Engineering in Agriculture and Rural Development, 14.1: 147-152.

Hontus, A.C., (2013). Study on Tourist Traffic Analysis for Tourism Area Planning in the Town of Moreni, Dâmboviţa County, Bulletin UASVM Horticulture, 70.2: 331-338.

Siggelkow, N., (2007). Persuasion with Case Studies, Academy of Management Journal, vol. 50, No. 1, 20-24.
Yin, R.K, (2003). Case Study Research: Desing and Methods, 3rd edition, SAGE Publications International Educational and Professional Publisher

-----------(2013).Statistics Hotelsand Accommodations in West Java 2009-2013, National Central Bureau of Statistics (CBS), CBS of West Java Province

,(2015). Local Government Work Plan for the West Java province in 2016.

,(2014). Final Report of West Java Tourism Development Advisor, Tourism and Culture Office, West Java Province 